\title{
Home accidents in childhood
}

\author{
Robert J Haggerty
}

\begin{abstract}
This is the eighth paper in a series of Injury Classic. Our goal is to reprint one such paper in each issue to initiate newcomers to the field of these old, often quoted, and important contributions. As many are difficult to find, it should help all of us to have a copy at hand. Your suggestions about future articles are welcome. Write to the editor with details of your favourite, most quoted paper.
\end{abstract}

\section{Department of Pediatrics, Harvard Medical School, the Children's Medical Center and the Boston Poison Information Center}

Supported by grants from the Commonwealth Fund and the Charles $\mathrm{H}$ Hood Dairy Foundation.

Associate in Pediatrics, Harvard Medical School; ssociate physician and chief, Child Health Division, Children's Medical Center director Boston Poison Information Center, Boston,
Massachusetts.

This paper first appeared in the New England fournal of Medicine (1959; 260:

$1322-31$ ) and is reprinted by permission. Copyright (1959) Massachusetts Medica Society.
The following and many similar headines startle parent and physicians daily: 'Girl dead, boy blinded by antifreeze'; 'Three small children perish in home fire'; and 'Boy, two, dies in two-story fall'. To the physician, who today can usually successfully treat his child patients for such serious illnesses as meningitis, erythroblastosis fetalis and dehydration, it is particularly frustrating to be faced with the death or serious injury of one of these children from an accident; yet except for the first year of life accidents are the single greatest cause of death during childhood ${ }^{1}$ (table 1).

In 1956 accidents caused over 10000 deaths in children from 1 to 14 years of age in the United States - more than the combined total of the next four causes ${ }^{1}$ (fig 1), and the importance of accidents as a cause of death rises throughout childhood until during adolescence over $50 \%$ of all deaths are due to accidents ${ }^{2}$ (fig 2). Even these striking statistics fail to emphasize the full importance of accidents in childhood, however, for it is estimated that 150 to 200 children are non-fatally injured for each accidental death, and of these, one in 40 is left permanently crippled.

Lest one be led to believe that this importance of accidents in childhood mortality and morbidity is due to a recent increase in accident rates, it is pertinent to point out that the death rates from accidents actually declined $42 \%$ from 1928 to $1957 .^{1}$ This decline is primarily due to improvement in the care of the victim and not the result of a decrease in the rate of accidental injury. During the same period, however, mortality from most other causes in childhood declined even more dramatically, leaving accidents as the most common serious health problem of childhood today.

\section{Home accidents}

Home accidents account for $38 \%$ of all accidental deaths in children under 15 years of age, and in the age group under five, $58 \%$ of accidental deaths occur in or about the home. ${ }^{2}$ If non-fatal accidents are added, the rate of all accidents occurring in the home varies from $51.6 \%$ at 10 to 14 years of age to $91.3 \%$ for children under 1 year of age ${ }^{3}$ (fig 3 ).

In the course of a year, nearly one in every five children under 15 years of age suffers some home accident serious enough to cause 'restricted activity for at least one day' (fig 4).

\section{ETIOLOGY}

Detailed information about the etiology of home accidents is not now available. It seems reasonable that there are many causes, perhaps quite different for different types of accidents. For example the etiology and pathogenesis of poisonings may differ as much from those of drownings as the causes of typhoid fever do from those of influenza. The facts now known about etiology of home accidents can be best described under the same divisions that have proved useful in describing the causes of infections: the agent; the host; and the environment. ${ }^{5}$

\section{Agents causing home accidents}

Most accident statistics combine the nature of the injury (burns, falls, and so forth) with the specific agents (fire, stairs, and so forth) involved, and this leads to some confusion when one is trying to make comparisons between different geographic areas. Table $2^{1}$ lists the agent or nature of injury of all fatal home accidents in the United States for 1956, and table $3^{67}$ lists the same data collected from one community for all accidents (fatal and nonfatal, home and outside) for 1954. From these data it is apparent that burns are a relatively uncommon cause of all home accidents (about 3\%) but tend to threaten life when they do occur and account for about $20 \%$ of all home accident fatalities. Falls on the other hand, are responsible for nearly $40 \%$ of all accidents in childhood, and yet cause only about $5 \%$ of the accidental deaths.

These statistics are relatively unsatisfactory for a full understanding of the pathogenesis of home accidents, since they add little to knowledge of why a particular child suffers a particular accident on a particular day. In addition, they fail to point out local geographic variations that affect the type of accident risk such as kerosene in rural areas and drownings near seashores. They are frequently imprecise, for mechanical suffocation is still listed as the most frequent cause of accidental death in infancy, and yet careful studies ${ }^{89}$ show that these babies usually die from other causes, particularly overwhelming infection, and children who actually die as a result of accidents (burns, fractures, and so forth) may be listed under one of the complications, such as pneumonia or shock, rather than the primary cause, accidents.

By and large the national statistics are of most value in educating physicians and parents concerning the general hazards for different age groups. Detailed analysis of local statistics (hospital, private physician, or community) may indicate specific hazards peculiar to an area. Excellent examples of how detailed studies of one type of accident - burns - can 
Table 1 Death rates from leading causes in the United States, 1956*

\begin{tabular}{|c|c|c|c|c|c|}
\hline Cause of death & $\begin{array}{l}\text { Children } \\
<1 \text { year }\end{array}$ & $\begin{array}{l}\text { Cause of } \\
\text { death }\end{array}$ & $\begin{array}{l}\text { Children } \\
1-4 \text { years }\end{array}$ & $\begin{array}{l}\text { Cause of } \\
\text { death }\end{array}$ & $\begin{array}{l}\text { Children } \\
5-14 \text { years }\end{array}$ \\
\hline Immaturity & 622 & Accidents & 31 & Accidents & 20 \\
\hline Postnatal asphyxia & 495 & Pneumonia & 15 & Cancer & 7 \\
\hline $\begin{array}{l}\text { Congenital } \\
\text { malformations }\end{array}$ & 429 & $\begin{array}{l}\text { Congenital } \\
\text { malformations }\end{array}$ & 13 & $\begin{array}{l}\text { Congenital } \\
\text { malformations }\end{array}$ & 3 \\
\hline Pneumonia & 322 & Cancer & 11 & Pneumonia & 2 \\
\hline Birth injuries & 315 & Enteritis & 4 & Nephritis & 1 \\
\hline Accidents & 96 & Meningitis & 2 & Rheumatic fever & 1 \\
\hline Total deaths & 2963 & & 110 & & 47 \\
\hline
\end{tabular}

«Based on Accident Facts. ${ }^{1}$

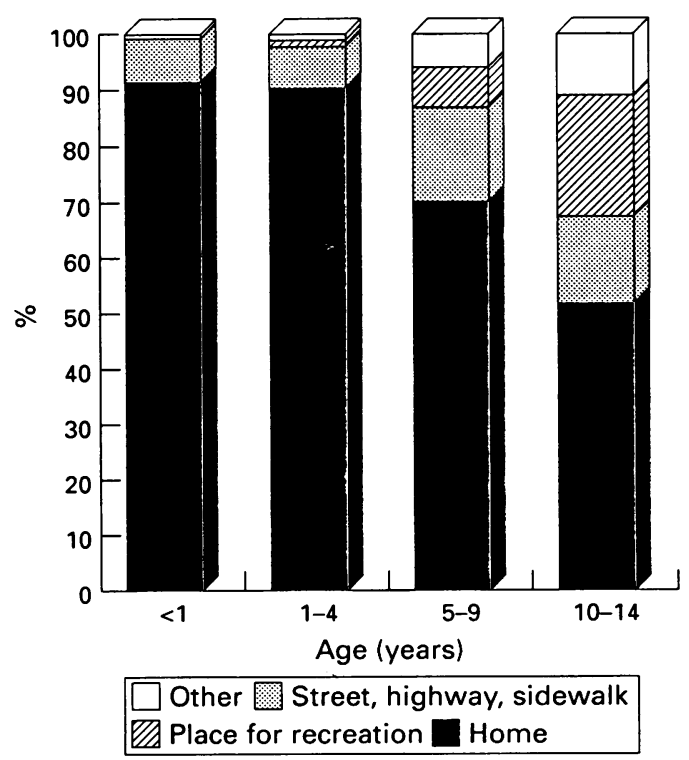

Figure 3 Accidental injuries according to age and place of accident (reproduced with permission from United States Public Health Service Accident Prevention Program ${ }^{3}$ ).

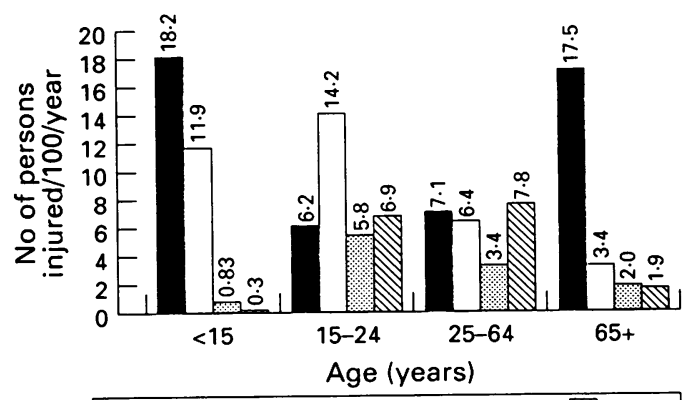

Home $\square$ Other $[$ Motor vehicle Work

Figure 4 Types of accidents and number of injuries $/ 100$ persons/year (based on Health Statistics from the United States National Health Survey).

Figure 2 Accidents expressed as a percentage of all deaths (based on Vital Statistics of the United States ${ }^{2}$ ).

lead to a better understanding of the causes and point the way toward control are the report by Bleck $^{10}$ of the agents involved in some 457 patients with severe burns hospitalized in North Carolina, and the review of 1000 cases of burns in England by Colebrook. ${ }^{11}$

\section{The environment}

In an effort to learn more about the causes of home accidents, the environment has also been extensively studied and, for analysis, can usefully be divided into physical and social environment.

Physical environment - Death rates from accidents vary considerably from country to country; for instance, the death rate from accidental poisoning per 100000 male population 1 to 19 years of age varies from 0.3 in Sweden to 1.5 in Australia, ${ }^{12}$ but the reasons for this fivefold difference between two countries of somewhat similar ethnic and economic level are not clear. Home accidents are more common in urban areas; the rate per 100 persons per year varies from 11.3 in cities to 9.7 in rural farm areas. ${ }^{4}$

Seasonal variations are relatively minor and are generally well explained by the differences in types of accidents at different times of the year.

In a study of home accidents in Cambridge, Massachusetts, Curry and Sternfeld ${ }^{13}$ found the accident rate in certain federal and state housing projects to be twice that for the rest of the city, and others ${ }^{14-19}$ have reported a similar association of accidents with 'poor' housing; however there is usually a higher proportion of preschool children in housing projects and 'poor' housing, and this age group is known to have a higher accident rate. In one study ${ }^{13}$ only $20 \%$ of all home accidents could be directly attributed to defects of the physical environment, and it seems, in most cases, that the inceased accident rate in this type of housing is related to the nature of the host living there.

The area in the home where accidents occur has been extensively documented (fig 5$)^{13}$ and is useful in alerting parents and physicians to 
Table 2 Fatal home accidents according to the nature of the injury, by age, United States, $1956^{\star}$

\begin{tabular}{|c|c|c|c|c|}
\hline \multirow[t]{2}{*}{$\begin{array}{l}\text { Cause of } \\
\text { accident }\end{array}$} & \multicolumn{2}{|c|}{ All ages of childhood } & \multirow{2}{*}{$\begin{array}{l}\text { Children } \\
0-4 \text { years } \\
\text { of age } \\
\text { No of } \\
\text { accidents }\end{array}$} & \multirow{2}{*}{$\begin{array}{l}\text { Children } \\
5-14 \text { years } \\
\text { of age } \\
\text { No of } \\
\text { accidents }\end{array}$} \\
\hline & $\begin{array}{l}\text { No of } \\
\text { accidents }\end{array}$ & $\begin{array}{l}\text { Percentage } \\
\text { of total }\end{array}$ & & \\
\hline Fires, burns & 1800 & $20 \cdot 6$ & 1250 & 550 \\
\hline Mechanical suffocation & 1250 & $14 \cdot 3$ & 1250 & \\
\hline Obstruction from food or objects & 1150 & $13 \cdot 2$ & 1150 & \\
\hline Drowning & 1435 & $16 \cdot 4$ & 250 & $1185^{\dagger}$ \\
\hline Falls & 490 & $5 \cdot 6$ & 400 & 90 \\
\hline Poisons, including gases & 520 & 5.9 & 420 & 100 \\
\hline Firearms & 400 & $4 \cdot 6$ & 80 & 320 \\
\hline Other & 1690 & $19 \cdot 4$ & 1450 & 240 \\
\hline Totals & 8735 & $100 \cdot 0$ & 6250 & 2485 \\
\hline
\end{tabular}

^Based on Accident Facts. ${ }^{1}$

†Includes drownings outside home.

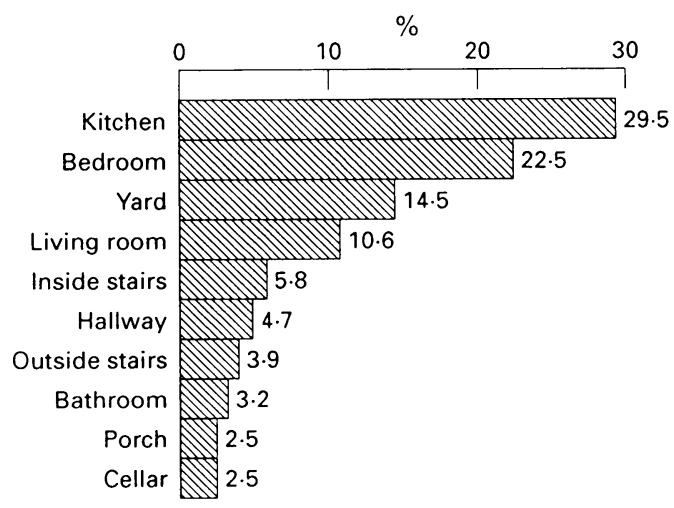

Figure 5 Place of occurrence of 9871 home accidents (based on Curry and Sternfeld ${ }^{13}$ ).

some of the different areas of risk, but is not of great help in explaining why accidents occur in these different locations.

There are interesting minor variations in the frequency of accidents by time of day and day of week: afternoons and weekends are slightly more likely to be the time when home accidents occur, indicating that fatigue or presence of more people in the home may play a minor part in the cause of some accidents.

Social environment - Since the preschool child is almost always under the supervision of someone else (his social environment) it is reasonable to examine the role of these supervisory persons in accidents occurring in this group. Bronzi and Johnson ${ }^{17}$ studied in detail some 50 home accidents in Cambridge. They found that the absence of a supervisory person (or, if such a supervisory person was present, he was not paying attention to the child at the time of the accident) - that is, the child's social environment - was the most common dominant factor in the cause of these accidents. In a social study of 419 poisonings in Australia, ${ }^{18} 27^{\circ}$ o of the mothers were unaware that the substance taken was actually poisonous. If these figures are found to be similar in the United States, they indicate the relative importance of education in the control of this one type of accident.

Backett and Johnston ${ }^{19}$ studied social patterns in pedestrian road accidents of children in England. In a comparison with children who had not suffered such accidents, they found several interesting correlations: a higher prevalence of family and maternal illness; greater crowding; less protected play; greater previous accident rate in family members; and 'poor cooperation' with school health services. There was no correlation with intelligence or family size.

The role of the child's peers and other aspects of his social environment is also suspected of being important, particularly in the school age group, but has been little studied.

\section{Host differences}

Differences in host factors have naturally intrigued investigators in accident research but have proved the most elusive and difficult to describe accurately. McFarland and Moore ${ }^{20}$ have reviewed the human factors in relation to highway accidents, but similar extensive studies regarding childhood home accidents, have yet to be completed.

The clearest evidence of the great importance of the host factors in childhood accidents is the marked contrast in the rate of specific accidents at different ages of childhood, for clearly the child is a quite different host at different ages. During the first year of life, when the child is relatively immobile, the hazards are unlike those of the beginning runabout, and these in turn are distinct from those of the nursery school child. Table 3, from the New Bedford study, is a valuable indication of the different accident risks at various ages

Table 3 Accidents (fatal and non-fatal) according to nature of injury by age, New Bedford, Massachusetts 1954

\begin{tabular}{|c|c|c|c|c|c|c|c|c|c|}
\hline \multirow[t]{2}{*}{ Cause of accident } & & \multicolumn{2}{|l|}{ All ages } & \multirow{2}{*}{$\begin{array}{l}\text { Children } \\
<1 \text { year } \\
\text { of age } \\
\text { No of } \\
\text { accidents }\end{array}$} & \multirow{2}{*}{$\begin{array}{l}\text { Children } \\
1-4 \text { years } \\
\text { of age } \\
\text { No of } \\
\text { accidents }\end{array}$} & \multirow{2}{*}{$\begin{array}{l}\text { Children } \\
5-9 \text { years } \\
\text { of age } \\
\text { No of } \\
\text { accidents }\end{array}$} & \multirow{2}{*}{$\begin{array}{l}\text { Children } \\
10-14 \text { years } \\
\text { of age } \\
\text { No of } \\
\text { accidents }\end{array}$} & \multirow{2}{*}{$\begin{array}{l}\text { Children } \\
15-16 \text { years } \\
\text { of age } \\
\text { No of } \\
\text { accidents }\end{array}$} & \multirow{2}{*}{$\begin{array}{l}\text { Age not stated } \\
\text { No of } \\
\text { accidents }\end{array}$} \\
\hline & & $\begin{array}{l}\text { No of } \\
\text { accidents }\end{array}$ & Percentage & & & & & & \\
\hline All causes & & 2097 & & 53 & 708 & 720 & 442 & 133 & 41 \\
\hline Falls & & 818 & $39 \cdot 0$ & & & & & & \\
\hline $\begin{array}{l}\text { Same level } \\
\text { Different level }\end{array}$ & $\begin{array}{l}405 \\
413\end{array}$ & & & $\begin{array}{r}3 \\
29\end{array}$ & $\begin{array}{l}122 \\
175\end{array}$ & $\begin{array}{l}152 \\
116\end{array}$ & $\begin{array}{l}96 \\
67\end{array}$ & $\begin{array}{l}25 \\
18\end{array}$ & $\begin{array}{l}7 \\
8\end{array}$ \\
\hline Impact & & 585 & $28 \cdot 0$ & 9 & 141 & 236 & 135 & 57 & 7 \\
\hline Cutting or piercing & & 225 & $10 \cdot 7$ & 1 & 42 & 95 & 63 & 12 & 12 \\
\hline Animal bites & & 143 & 6.8 & - & 38 & 63 & 36 & 3 & 3 \\
\hline Poison & & 75 & $3 \cdot 6$ & 2 & 71 & - & 2 & - & - \\
\hline Burn & & 71 & $3 \cdot 4$ & 7 & 36 & 8 & 14 & 4 & 2 \\
\hline Crushing & & 61 & $2 \cdot 9$ & - & 29 & 23 & 6 & 3 & - \\
\hline Foreign body & & 32 & 1.5 & 1 & 22 & 3 & 4 & 1 & 1 \\
\hline Other & & 87 & $4 \cdot 1$ & 1 & 32 & 24 & 19 & 10 & 1 \\
\hline
\end{tabular}


and, although based on a relatively small sample, does not have the defect of containing questionable diagnoses (such as mechanical suffocation) as the national mortality figures do. ${ }^{1}$

\section{HOME ACCIDENTS AT DIFFERENT AGES}

Under 1 year, falls from different levels are the most common home accident and involve the infant rolling from a bed, table, chair or bathinette, or toppling from a high chair. These acts usually occur when the parents believe that their child is still unable to roll or climb, or when the supervising person temporarily leaves the room. Although less frequent, burns are usually more serious. They involve the infant as an 'innocent bystander' in home conflagrations, or his contact with electricity, open fires, radiators, stoves, or scalding from hot liquids. Poisonings in this age group are more likely to be mistakes in administration of medication than accidental ingestion by the child, but the precocious baby who becomes ambulatory early is certainly a candidate for accidental poisoning.

Children 1 through 4 years are usually grouped together in accident statistics; yet within this narrow age range there are wide variations in the motor and intellectual abilities and consequently in the types of accidents. The majority of poisonings occur in the children 1 and 2 years old, whereas by 4 years of age this hazard has markedly decreased as the child learns increasing discrimination. Deaths from drownings, falls, and burns continue at a high level throughout this age group, indicating a somewhat different pathogenesis for these accidents from that of poisoning. Falls continue as a very common but less lethal type of accident, and collision with various objects plays a major part. Mammalian bites are quite common $^{21}$ but unlikely to be fatal.

During the school years the increasing motor skills, knowledge, and longer absence from the home lead to diminished incidence of all home accidents, with an increase in other accidents outside the home - drownings, motor vehicles, and firearms.

From these marked variations in types of accidents at different ages, it appears that the developmental level of the child (host differences) would influence his susceptibility to accidents, and although this question is under study in several places, results have not been reported.

The presence of a physical disability as another host factor has been suggested as important in the etiology of accidents; yet Lossing and Goyette 22 found only $2.5 \%$ of home accident victims suffering from such a physical defect.

The sex difference in rates for almost all types of home accidents is another intriguing example of host differences, for the generally greater number of accidents among boys ${ }^{23}$ suggests that personality, motor skills, and child rearing of boys is a causal factor. The fact that only accidental deaths under 1 year of age and those from fires, explosions, and scalds at all ages of childhood fail to show this sex difference (all accidents in which the child is usually only a passive victim to some adult action) adds weight to this argument.

Broussard, ${ }^{24}$ in a study of 1168 accidents in Florida, again demonstrated the preponderance of males in childhood accidents and suggested that parental attitudes toward boys, rather than simple physical factors such as agility, may be the important variable in causing more accidents in males.

Investigations to determine if there is indeed a difference in the personality of children who sustain accidents have concentrated on the 'accident repeater' as the epitome of an accident-prone child, if there is such an entity. The extent of accident repeaters, however, is in doubt. Allan and Williams, ${ }^{18}$ in Australia, found that $22 \%$ of 419 children seen for poisonings had previously swallowed a poisonous substance. These authors characterize the child likely to ingest poisons as 'intelligent, very active and mischievous . . .' Jacobziner, ${ }^{25}$ on the other hand, stated that only $1.9 \%$ of a large series of accidental poisonings reported to the New York Poison Control Center occurred in 'repeaters'.

Others have investigated specific types of patients in an effort to define personality characteristics of the accident-prone child. Craig, ${ }^{26}$ in England, studying 25 children seen for accidental poisonings and 25 'normal controls', found that 'exaggerated oral traits' were present in $76 \%$ of the former and in only $28 \%$ of the so-called normal group.

Several other studies ${ }^{27-29}$ have similarly characterized the child to whom accidents are likely to occur as one who "has superior gymnastic skill and strengths, more aggressive behavior, attempts to dominate social situations, is a poor loser, is less popular, rude, overactive, restless and impulsive'. All these studies suffer from small size, inadequate controls, or methods of evaluation not accepted by all workers. The general consistency of the findings, however, suggests that further large scale, well controlled studies in this field might be productive of a more precise definition of the role of certain personality types in the etiology of childhood accidents.

Yet to be studied are the family incidence of accidents, the effects of various child rearing practices, the child's previous experience with accidents, the parents' values and attitudes and the effect of such socially disruptive events as broken homes, frequent moves, or other illness in the home in the etiology of accidents.

It seems apparent from these studies, which represent the majority of reported work on the etiology of home accidents in childhood, that exact definition of a single causal factor probably is not a reasonable expectation, since there are so many quite different types of child accidents, each with a multiplicity of possible causes. The concept of 'multiple causation' is thus an attractive one to explain these many variations more adequately, with a different weighting of the variables of agent, host and environment in each case. The concept of 'total accident situation' (fig 6$)^{30}$ is useful to an 


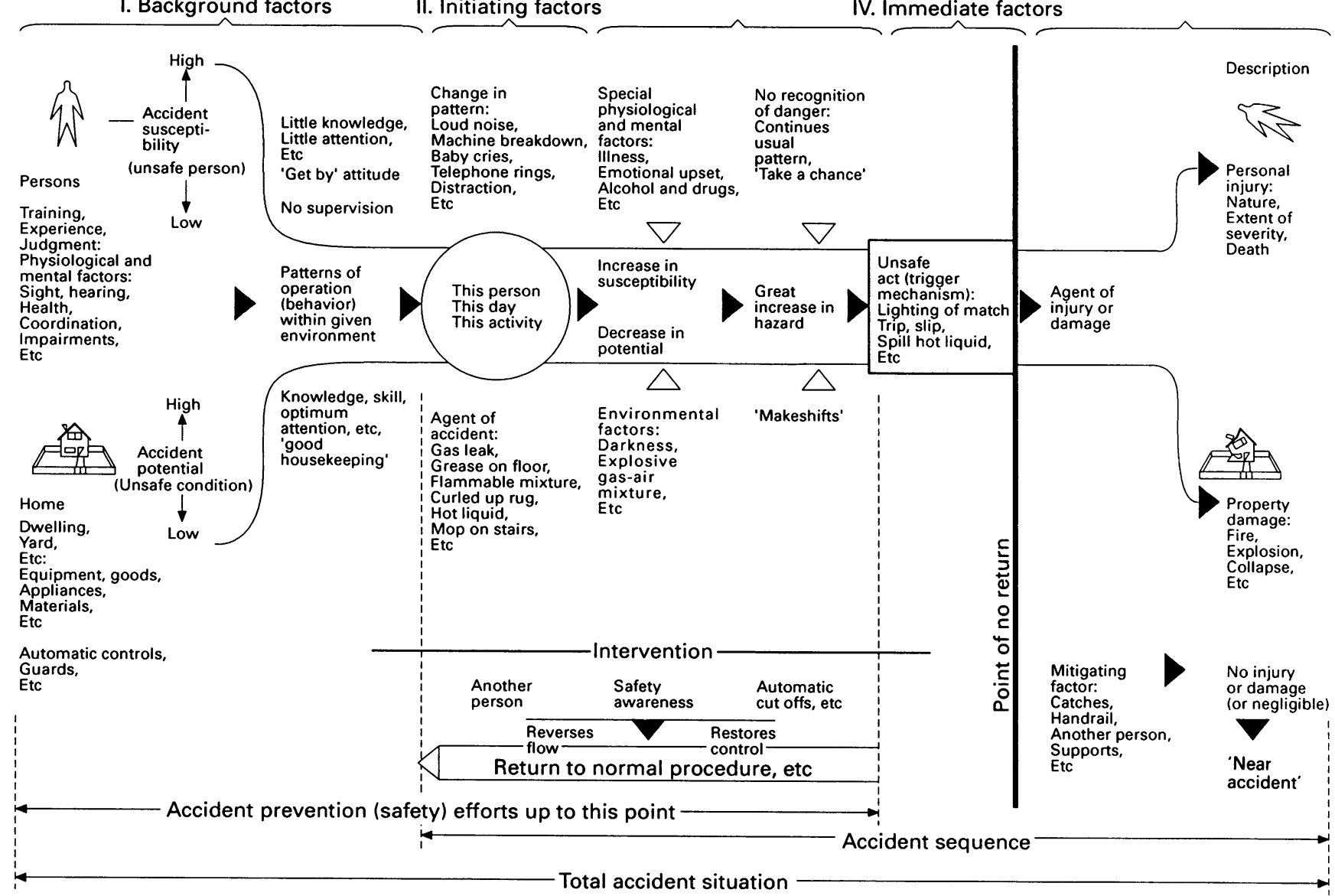

Figure 6 Dynamics of home accidents (reproduced with permission from Uniform Definition of Home Accidents ${ }^{30}$ ).

understanding of how the multiples of background, initiating, intermediate, and immediate factors all converge in certain persons to lead to an accident. Everyone has daily experiences that could combine to produce an accident. What is not known is why intervention of one type or another occurs, in most cases, to prevent the accident entirely, or mitigating factors intervene to make the injury negligible. When thought of in this broader concept, accidents are thus part of daily living: their seriousness may vary from time to time in the same person, or in different persons, making one accident a 'statistic' whereas the remainder are entered only in the experience file of each.

\section{Emergency treatment of common home accidents in childhood}

Whatever his future role in prevention, the physician will continue to play a major part in the therapy of accidents. It is beyond the scope of this review to discuss the details of management of the many different types of accidents. Every physician who treats acute problems of childhood, however, will be called upon frequently to render emergency care to the accident victim. The Committee on Accident Prevention of the American Academy of Pediatrics has recently published a very brief outline of recommended emergency care of childhood skeletal trauma and burns, which is summarized below. ${ }^{31}$

Emergency care of childhood skeletal trauma

1. Evaluate and splint where they lie before moving. Do not attempt reduction.

2. Move cervical injuries face up on a rigid support with manual traction applied gently by cupping chin at the time of moving. Sandbags on either side of neck to prevent turning, if possible.

3. Spine injuries should not be flexed in transportation.

4. Lower leg injuries, transport in pillow strapped with belt.

5. Upper leg injuries, transport with both legs and trunk bound to board without circulatory interference.

6. Lower arm injuries, transport with splint such as rolled newspaper, gentle compression wrapping and sling.

7. Upper arm can be bound to chest with lower arm supporting in sling.

8. Open injuries or open wounds, cover with sterile dressing, do not dust with antibiotic, but systemic antibiotic is useful. Do not attempt to retract bone back under skin. Get to surgical care promptly.

9. Do not cover distal tips of extremities if it can be avoided, thus allowing a circulation check to be made from time to time.

\section{Emergency care of burns}

1. Burns are due to thermal agents (scalds or fire); chemical agents (battery acid or lye); radiation (sunburn or nuclear); and electrical energy. 
2. Even small burns may be followed by infection, tetanus, excessive scarring, and disfigurement. Large burns may represent an immediate threat to life from shock. Arrest of the circulation and respiration may occur following electrocution.

3. Flames should be smothered if possible with child horizontal; children who have been scalded should have their clothing removed immediately; chemical burns (except phosphorus) should be washed with large quantities of running water. Chemical burns of the eye should be flushed with saline solution or water. Patients should be removed from source of radiant energy.

4. Fresh burns are relatively clean. They should be covered by a clean cloth immediately and should not be uncovered until the patient is delivered to a hospital emergency room or a doctor's office. Such covering should be loosely applied without constriction.

5. Ointments, greases, powders, etc, should not be used in the emergency treatment of burns. Leave this management to the physician who will care for the patient. 6. Shock may be combated by keeping the patient flat, reassuring him, and keeping him warm during the transportation to the hospital.

7. Pain is usually not a serious problem in the emergency treatment of a burn and drugs for pain should not be administered except by the physician who will care for the burn.

8. Patients with burns of the face, hands, feet or areas surrounding a joint, as well as any burn equivalent to more than $5 \%$ of the body surface, should be hospitalized after emergency treatment.

9. Electrical burns accompanied by electrocution and failure of respiration and circulation should receive artificial respiration for an indefinite period and until ordered to stop by a physician.

The evaluation and emergency therapy of head injuries is well outlined in a recent textbook, ${ }^{32}$ which emphasizes the most significant feature in the management of all patients with closed head injuries - namely, 'repeated, careful notation of the vital signs and neurological status at regular intervals until complete recovery has occurred'. This generally means hospitalization for children rendered unconsious by the injury. Other patients with milder cases may be followed at home if the parents are capable of the frequent observations necessary. Depressed fractures, compound fractures, or signs of increasing intracranial pressure are obviously indications for neurosurgical consultation.

Certain principles in the early management of accidental poisons have been outlined ${ }^{33}$ : identification of the toxic agent; prompt removal of the agent; institution of general supportive measures; and use of specific antidotes when available.

If precise identification of the potentially toxic agents is not possible from the label, consultation with one of the more than 200 poison information centers ${ }^{34}$ in the United States may be of great help.

Recent work $^{35}$ has demonstrated that induced emesis is a far more effective means of removing ingested poisons than the traditional lavage. If certain precautions are taken (for example, no induced vomiting after ingestion of caustics or hydrocarbons, and the child's head being held down), this is a safe procedure for parents to perform on a physician's advice, for valuable time can be saved and more effective removal of the toxic agent accomplished.

General supportive measures such as maintaining an airway, blood pressure and respira- tions, and sedatives for convulsions are generally the most important aspect of therapy, for there are relatively few specific antidotes available. Recently, exchange transfusion or artificial kidney hemodialysis has been successfully employed to remove a great variety of poisons from the blood stream.

Specific antidotes such as BAL (dimercaprol) for mercury or arsenic, n-allyl morphine for opiate and atropine or 2-PAM (pyridine ald-oxide methiodide) for phosphate ester insecticide poisonings should be promptly employed when indicated.

\section{Prevention}

In the present state of incomplete knowledge concerning all the factors in the etiology of accidents, prevention cannot be expected to be complete. In fact there is little question that minor accidents are a necessity for the growing child to learn about his environment and his own capabilities. The problem is to learn how to prevent the life threatening or crippling accidents without imposing such restrictions on the development of the child that serious emotional problems ensue.

Few studies have been reported on the effectiveness of various preventive measures. One indirect attempt to determine this involved an evaluation of an extensive educational effort by a state health department. ${ }^{36} \mathrm{By}$ organization of parent groups throughout the state and distribution of a questionnaire on accident hazards, over 35000 households were alerted to the accident hazards in the home. Whether changed behavior occurred as a result could not be determined.

In another evaluation of a large scale educational program by the Michigan Health Department, ${ }^{37}$ it was found that $27 \%$ of the households surveyed stated that they had followed some of the safety advice given. Even more impressive was the fact that the home accident death rate for the state dropped by $50.4 \%$ one year after the institution of the campaign. Although this was not a controlled study and many other variables could have accounted for the reduction, it is one of the very few reports actually to show a decrease in accidents after any preventive program.

How effective education alone can be in reducing home accidents is not known. From what has been discussed of the many causal factors, however, it seems reasonable that a significant reduction in childhood accidents could be achieved if parents became aware of the normal development at different ages of children, the specific hazards dependent upon these developmental levels, and the particular capacities and limitation of their own children.

Dietrich $^{38}$ has written very dramatically of the practical aspects of a method of prevention that can be utilized by health practitioners, physicians, public health nurses, and other members of the health team. The essence of this method is depicted in figure $7,^{38}$ which indicates that almost complete protection against accident hazards must be carried out during the first year of life; after this period 
gradual reduction in protection and increase in education must occur, or the child may arrive at school age over protected and unprepared for the realistic hazards of road accidents, games, swimming ponds and so forth.

Specific hazards common to each age group and dependent primarily upon the developmental level of the child at each of these

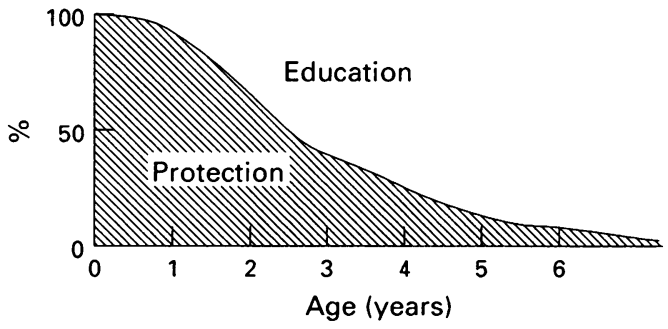

Figure 7 Theory of accident prevention (reproduced from Dietrich ${ }^{38}$ with the permission of the publishers).

Table 4 Accident risks and precautions at various age levels $\star$

\begin{tabular}{|c|c|c|}
\hline Typical accident & $\begin{array}{l}\text { Normal behavior } \\
\text { characteristics }\end{array}$ & Precautions \\
\hline \multicolumn{3}{|l|}{ 1st year: } \\
\hline Falls & $\begin{array}{l}\text { Rolls over about } 4 \text { mo. of age; } \\
\text { creeps, stands and may walk } \\
\text { between } 6 \text { and } 12 \text { mo. }\end{array}$ & $\begin{array}{l}\text { Do not leave alone on tables, } \\
\text { beds or bathinette; keep crib } \\
\text { sides up }\end{array}$ \\
\hline Burns & $\begin{array}{l}\text { Is helpless to leave (burning } \\
\text { house) source of burn }\end{array}$ & $\begin{array}{l}\text { Keep electric cords and appliances } \\
\text { away; do not leave in house } \\
\text { alone; test water in bath }\end{array}$ \\
\hline $\begin{array}{l}\text { Inhalation or } \\
\text { ingestion of }\end{array}$ & Puts everything in mouth & $\begin{array}{l}\text { Keep small objects and poisons } \\
\text { out of reach }\end{array}$ \\
\hline Poisonings & & \\
\hline Drowning & Is helpless in water & Do not leave alone in bath \\
\hline \multicolumn{3}{|l|}{ 2nd year: } \\
\hline Falls & $\begin{array}{l}\text { Is able to walk; can go up and } \\
\text { down stairs }\end{array}$ & $\begin{array}{l}\text { Keep screens on windows and } \\
\text { gate at stairs }\end{array}$ \\
\hline Burns & $\begin{array}{l}\text { Reaches for any utensils on } \\
\text { stove or table }\end{array}$ & $\begin{array}{l}\text { Keep handles of pots and pans on } \\
\text { stove out of each and hot foods } \\
\text { away from edge of table; keep } \\
\text { electric cords out of reach; } \\
\text { cover unused electric outlets; do } \\
\text { not leave alone in house }\end{array}$ \\
\hline Drowning & Is helpless in water & $\begin{array}{l}\text { Keep in enclosed space when out- } \\
\text { doors or not in company of } \\
\text { adult }\end{array}$ \\
\hline Poisonings & $\begin{array}{l}\text { Has great curiosity; puts } \\
\text { everything into mouth }\end{array}$ & $\begin{array}{l}\text { Keep medicines, household } \\
\text { compounds and small, sharp } \\
\text { objects out of reach }\end{array}$ \\
\hline \multicolumn{3}{|l|}{ 2-4 years: } \\
\hline Falls & $\begin{array}{l}\text { Is able to open doors; can run } \\
\text { and climb, can throw ball, } \\
\text { ride tricycle }\end{array}$ & $\begin{array}{l}\text { Keep doors locked where danger } \\
\text { of falls - cellar, screens on } \\
\text { windows; teach risks of throwing } \\
\text { sharp objects }\end{array}$ \\
\hline $\begin{array}{l}\text { Drowning } \\
\text { Poisonings }\end{array}$ & Investigate closets and drawers & \\
\hline Burns and cuts & & $\begin{array}{l}\text { Keep knives and electric equip- } \\
\text { ment out of reach }\end{array}$ \\
\hline $\begin{array}{l}\text { Firearms } \\
\text { Motor vehicle }\end{array}$ & Plays with mechanical gadgets & $\begin{array}{l}\text { Keep firearms locked up } \\
\text { Teach safety in street and } \\
\text { driveway }\end{array}$ \\
\hline \multicolumn{3}{|l|}{ 5-9 years: } \\
\hline $\begin{array}{l}\text { Motor vehicle } \\
\text { Bicycle accidents }\end{array}$ & $\begin{array}{l}\text { Is daring and adventurous } \\
\text { Control more advanced over large } \\
\text { than over small muscles }\end{array}$ & Teach traffic and bicycle safety \\
\hline $\begin{array}{l}\text { Drowning } \\
\text { Burns }\end{array}$ & & $\begin{array}{l}\text { Encourage but do not push } \\
\text { swimming skills }\end{array}$ \\
\hline $\begin{array}{l}\text { Burns } \\
\text { Firearms }\end{array}$ & & Keep firearms locked up \\
\hline Falls & $\begin{array}{l}\text { Loyalty to group makes him } \\
\text { willing follow older leaders }\end{array}$ & \\
\hline \multicolumn{3}{|l|}{ 10-14 years: } \\
\hline Motor vehicles & $\begin{array}{l}\text { Need for strenuous physical } \\
\text { activity }\end{array}$ & $\begin{array}{l}\text { Teach rules of pedestrian and } \\
\text { traffic safety; prepare for } \\
\text { automobile driving by setting } \\
\text { good example }\end{array}$ \\
\hline $\begin{array}{l}\text { Drowning } \\
\text { Burns }\end{array}$ & $\begin{array}{l}\text { Plays in hazardous places } \\
\text { Need for approval of agemates }\end{array}$ & Provide safe and acceptable \\
\hline Falls & $\begin{array}{l}\text { leads to daring or hazardous } \\
\text { feats }\end{array}$ & $\begin{array}{l}\text { facilities for recreation and } \\
\text { social activities }\end{array}$ \\
\hline
\end{tabular}

${ }^{\star}$ Modified from Shaffer. ${ }^{39}$ age groups have been well summarized by Shaffer $^{39}$ (table 4). These can be relatively easily incorporated into the periodic health examinations as part of the anticipatory guidance of children. Helpful check lists have been prepared by several insurance companies ${ }^{40-43}$ that may be effectively distributed to parents after a discussion of the particular hazards and preventive points peculiar to the child involved. This approach seems, theoretically, to be a most effective method of accident prevention, for then the many variations in individual child development, parent knowledge, personality, and home environment could be taken into account. As stated above, whether this is actually an effective method has yet to be proved by appropriate studies.

Dietrich has argued that unpleasant experience be utilized as part of the education of the child to promote avoidance of accidents. When the child reaches for hot but not very dangerous objects, he urges parents to say, 'That's hot', but to realize that the child will touch, will be made uncomfortable, and will learn that although they tried to warn him, he had an unpleasant experience. In addition, it seems wise to let the child learn that minor accidents are part of living and not to shower special attention and false love upon him at these times - this may prevent his developing a sense of secondary gain to be derived from accidents. A common sense recommendation for parents, as so well put by Dietrich, ${ }^{44}$ is as follows:

... don't rob your child of the educational value of his minor injuries. If you reward him (his tears or his bruises or his bleeding) with honeyed words or sweets, he will probably forget his lesson, and may only remember that playing with fires begets cookies.

\section{Role of the individual physician in acci- dent prevention}

In spite of the large part many other professionals may play in the ultimate control of accidents, physicians by their close contact with individual families can probably do a great deal to limit the accident toll in childhood by the following means:

Incorporating the anticipatory guidance principles listed in table 4 in the routine care of patients, and using the pamphlet ${ }^{40-43}$ available to assist in this education program, as well as office bulletin boards with clippings and posters concerning accidents.

Lending their professional prestige and knowledge to community-wide programs in accident prevention on television or radio programs and at various parent meetings.

Utilizing the emotionally 'ripe' time during treatment of patients with injuries to transmit preventive principles - during home visits this can be very effective as actual environmental hazards are demonstrated.

Giving careful instructions, when prescribing medicine, for its proper and safe storage and prescribing only enough for the individual illness; sugar coated, candylike pills are probably unwise. 


\section{Research in progress}

From the foregoing summary of the state of knowledge about the causes and especially the prevention of childhood home accidents, it is apparent that there is a very extensive amount of research yet to be done before answers are found to most of the questions raised. It is gratifying to see the beginnings of this type of research, and although it was impossible to learn of all such projects, a description of the general nature of the studies now in progress or planned may be found useful. These can be conveniently grouped as follows:

\section{COMMUNITY BASED STUDIES}

The family injury survey of the Connecticut State Department of Health will involve collection of information on accidental injuries to all members of 2000 randomly selected households in Norwich, Connecticut (correlation of environmental and personality data with details of each injury will be performed).

The New Bedford accident prevention program, a four year longitudinal study of up to 700 births of primigravidas, to determine the rates and types of accidents correlated with the many background factors in each patient.

Accidental poisoning as a case finding procedure is a study by the San José City Health Department to determine if the homes in which accidental poisonings occur are also the ones in which there is a greater likelihood that other accidents will occur (if this proves to be true, a very useful method of selected case finding will be available to indicate where the greatest efforts at prevention should be concentrated).

Research projects on accidents by the New York City Department of Health are designed to obtain epidemiologic data on many types of accidents in the preschool group by survey of children attending child health conferences in New York City and the cases reported to the New York Poison Control Center.

Survey of accidental home injuries in Philadelphia is designed to determine the types of accidents and the environmental, physical and psychologic factors that contribute to them.

$A$ study of the number and circumstances of fatal and non-fatal accidents to farm residents in Pennsylvania by the Pennsylvania Rural Safety Council.

\section{INDIVIDUAL BASED STUDIES}

Studies of children showing injury patterns at Tulane University School of Medicine is designed to investigate the personality characteristics and family constellations of children 6 to 10 years of age who have repeated accidents.

Epidemiologic study of accidental poisonings in childhood by the Department of of Pediatrics, University of Louisville School of Medicine, is an investigation of patients reported to the poison control center at the institution.

$A$ pilot study of the details of the accident sequence in salicylate poisoning is designed to determine some of the child-rearing practices, parental attitudes and developmental levels of the child involved, as reported to the Boston Poison Information Center.

\section{Summary and conclusions}

The important role of accidents in general, and home accidents in particular, in childhood mortality and morbidity is outlined. The concept that best expresses the present state of knowledge concerning accident etiology is that of multiple causation, in which the variables of host, environment, and agent all play a part in each accident, but the importance of each of these factors varies from accident to accident. In children the marked difference in accident hazards at different developmental levels offers the most convincing evidence that differences in the host are of importance in etiology.

The most logical approach to prevention of accidents at present involves the integration of many members of the health team physicians, nurses, public health personnel, health educators, and lay groups. The role of the physician seems to be primarily in instruction of individual families in the accident hazards at different ages. His close relation to families and his familiarity with their home and personal characteristics indicate the crucial part that he can play in such prevention. Much research remains to elucidate the precise role of the various causes in different accidents, the identification of the susceptible host and the most effective means of prevention. Evidence that this type of research is at last beginning offers hope that accidents may eventually yield to control measures.

1 Accident facts: 1958 edition. Chicago: National Safety Council, 1958: $96 \mathrm{pp}$.

2 United States Department of Health, Education and Welfare. Public Health Service, National Office of Vital Statistics. Vital statistics of the United States: 1955. Vol 2. Mortality data. Washington, DC: Government Printing Office, 1957: $317 \mathrm{pp}$.

3 Accident prevention program. Prepared by Department of Health, Education and Welfare. Public Health Service, Division of Special Health Services, February 1958.

4 United States Department of Health, Education and Welfare. Public Health Service. Health statistics from the United States national health survey. Washington DC: Government Printing Office 1958: 24 pp (publication No 584-135).

5 McFarland RA. Epidemiologic principles applicable to study and prevention of child accidents. Am $\mathcal{F}$ Public Health 1955; 45: 1302-8.

6 Rice RG, Starbuck GW, Reed RB. Accidental injuries to children. N Engl $₹$ Med 1956; 255: 1212-9.

7 Accidents reported fanuary 1-December 31, 1954. Prepared by Greater New Bedford Children's Accident Prevention Program, New Bedford, Massachusetts. (Mimeographed publication.)

8 Woolley PV. Mechanical suffocation during infancy: comment on its relation to total problem of sudden death. $\mathcal{f}$ Pediatr 1945; 26: 572-5.

9 Adelson L, Kinney ER. Sudden and unexpected death in infancy and childhood. Pediatrics 1956; 17: 663-97.

10 Bleck EE. Causes of burns in children: study of fullthickness burns in 457 patients from North Carolina Orthopedic Hospital, Gastonia. $\mathcal{F} A M A$ 1955; 158: $100-3$.

11 Colebrook L, Colebrook V. Prevention of burns and scalds: review of 1000 cases. Lancet 1949; ii: $181-8$.

12 Accidents in children: facts as basis for prevention. Tech Rep World Health Organ 1957; 118: 1-40.

13 Curry JI, Sternfeld L. Summary of home accident prevention project, City of Cambridge, Massachusetts, 1951-1956. Cambridge: Cambridge Department of Public Health. 1956; 23 pp. (Mineographed publication.)

14 Rowntree G. Accidents among childre under two years of age in Great Britain (some findings of national questionnaire inquiry). $\mathcal{f}$ Hyg 1950; 48: 323-37.

15 Seiter HE, Ramsey CB. Home accidents. Practitioner 1954; 172: $628-36$.

16 Britten RH. New light in relation of housing to health. $A m \mathcal{F}$ Public Health 1942; 32: 193-9.

17 Bronzi EI, Johnson GC. Study of fifty home accidents by public health nurses: comparison with previous studies. Epidemiology of home accidents, and health counseling. Thesis: Harvard School of Public Health, Cambridge, Massachusetts, 1967.

18 Allan J, Williams $\mathrm{H}$. Social study of accidental poisoning. Med f Aust 1956; i: 213-6. 
19 Backett EM, Johnston AM. Social patterns to road accidents to children. $B M F$ 1959: i: 409-13.

20 McFarland RA, Moore RC. Human factors in highway safety: review and evaluation. $N$ Engl $\mathcal{F}$ Med 1957; 256: safety: review and evaluation.

21 Carithers HA. Mammalian bites of children: problem in accident prevention. $\mathcal{F}$ Dis Child 1958; 95: 150-6

22 Lossing EH, Goyette RB. Review of 1000 home accident. Can f Public Health 1957; 48: 131-40.

23 Berfenstam R. Critical review on different types of accident morbidity studies. Courrier 1957; 7: 349-61.

24 Broussard ER. Relationship of sex to childhood accidents. $\mathfrak{f}$ Fla Med Assoc 1958; 44: 1343.

25 Jacobziner H. Accidents - major health problem. $\mathcal{F}$ Pediatr 1955; 46: 419-36.

26 Craig JO. Oral factors in accidental poisoning. Arch Dis Child 1955; 30: 419-23.

27 Birnback SB. Cited by McFarland, 5 p 1304

28 Fuller EM. Injury-prone children. Am $\mathcal{F}$ Orthopsychiatry 1948; 18: 708-23.

29 Langford WS, Gilder R, Wilking VN, Genn MM, Sherrill HH. Pilot study of childhood accidents: preliminary report. Pediatrics 1953; 11: 405-15.

30 United States Department of Health, Education and Welfare. Public Health Service. Uniform definition of home accidents. Washington, DC: Government Printing Office, $1958 ; 14$ pp (publication No 577).

31 Report: Committee on Accident Prevention: emergency care of childhood skeletal trauma and burns. Pediatrics 1957 20: 565 .

32 Ingraham FD, Matson DD. Neurosurgery of Infancy and childhood. Springfield, Illinois: Thomas, 1954: 1: 159 (456 pp).

33 Procedure book for the management of childhood poisoning. Prepared by Boston Poison Information Center, Boston, Massachusetts, 1956: 35 pp.

34 Cann HM, Neyman DS, Verhulst HL. Control of accidental poisoning: progress report. $¥ A M A$. 1958; 168: 717-24.

35 Arnold FJ Jr, et al. Evaluation of efficacy of lavage and induced emesis in treatment of salicylate poisoning. Pediatrics 1959: 23: 286-301.

36 Zindwer $R$. Educational project in childhood accident prevention. Am $\mathcal{F}$ Public Health 1955; 45: 438-41.

37 Prothro WB. Home accident prevention: research program. Am $\mathcal{F}$ Public Health 1951; 41: 954-8.

38 Dietrich HF. Accidents, childhood's greatest physical threat, are preventable. $\mathcal{F} A M A$ 1950; 144: 1175-9.

39 Shaffer TE. Symposium on clinical advances: accident prevention. Pediatr Clin North Am 1954; 1: 421-32.

40 Child safety suggestions. Prepared by Greater New Bedford Children's Accident Prevention Program with cooperation of New Bedford Medical Society, New Bedford, Massachusetts.

41 A formula for child safety. Prepared by Metropolitan Life Insurance Company, New York City, New York, 1955: $14 \mathrm{pp}$.

42 United States Department of Health Education, and Welfare, Food and Drug Administration, Division of Medicine. Protect your family against poisoning. WashingMed, DC: Government Printing Office, 1956.

43 AM-man says: 'Your home can be as safe as you make it'. Prepared by American Mutual Liability Insurance Company, Wakefield, Massachusetts, 1958.

pany, Wakefield, Massachusetts, 1958 .
44 Dietrich HF. Your child's safety. Prepared by Nationwide Insurance Company, Columbus, Ohio, 1955.

\section{Additional references}

Roberts HL, Gordon JE. Home accidents in Massachusetts: study in epidemiology of trauma. N Engl I Med 1949; 241 : 435-41.

Rosenfield AB. Childhood mortality from accidents. Minn Med 1952; 35: 424-9.

Starbuck GW. Recent trends in accident prevention. Pediatrics 1958; 22: 761-73.

Wheatley GM. Prevention of accidents in childhood. $A d v$ Pediatr 1956; 8: 191-215.

\section{Editorial Board Member: brief biography}

BERNARD GUYER

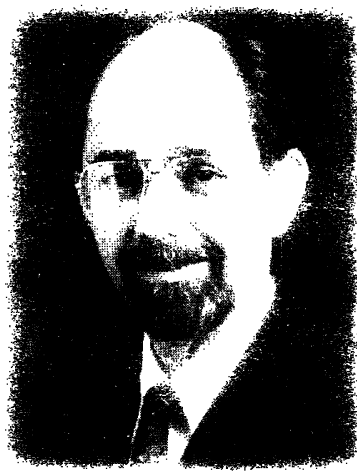

Bernard Guyer, MD, MPH, is Professor and Chair of the Department of Maternal and Child Health and an Associate Director of the Center for Injury Research and Policy, Johns Hopkins School of Hygiene and Public Health.

$\mathrm{He}$ trained in pediatrics and preventive medicine and served as an EIS officer at the Centers for Disease Control. From 1979 to 1986, Dr Guyer served as the Director of the Maternal and Child Health agency in the Massachusetts Department of Public Health, where he directed the Massachusetts Statewide Childhood Injury Prevention Program (SCIPP). SCIPP carried out landmark research on the epidemiology of childhood injuries and evaluated injury prevention programs in the community. Dr Guyer has published more than 20 research papers on injury spanning a broad array of topics including: injury epidemiology in Massachusetts, community based interventions, injury program implementation and evaluation, the epidemiology of burns in Ghana, and pedestrian safety.

From 1986 to 1989 Dr Guyer was an associate professor of $\mathrm{MCH}$ and Director of the Injury Prevention Center at the Harvard School of Public Health. He has been active in maternal and child health and childhood injury policy at the national level. He is currently a member of the Institute of Medicine's Board on Children and Families. Dr Guyer chaired the National Committee on Injury Prevention that published Injury Prevention; Meeting the Challenge. Dr Guyer's areas of injury research include the epidemiology of childhood injury, pedestrian injuries, and the implementation and evaluation of injury prevention programs. 